\title{
Pravica do javnih mestnih prostorov v Sarajevu: prostori, ki pripadajo vsem, nekaterim, komur koli ali nikomur?
}

Razni družbenopolitični in gospodarski dejavniki so postopno povzročili obsežno zanemarjanje, propadanje, zlorabo in izgubo javnih prostorov v Sarajevu. Navzkrižje zasebnih in javnih interesov je na mestu pustilo dejanske sledi in v takih okoliščinah se zdi Lefebvrov koncept pravice do mesta še toliko pomembnejši. $Z$ vidika sodobnega urbanega razvoja Sarajeva se navedena pravica nanaša na pravico do oblikovanja, uporabe, ponovne uporabe in ponovne aktivacije zanemarjenih skupnih prostorov $\mathrm{v}$ mestu. Kot je razvidno že iz naslova članka, je ključno vprašanje, $s$ katerim se avtorici ukvarjata, komu javni prostor sploh pripada. $\mathrm{V}$ raziskavi najprej določita ključne težave, povezane s propadanjem javnih prostorov, nato pa ovrednotita prevladujoče načrtovalske pristope in občasne pobude od spodaj navzgor. Predpostavljata, da so razpršenost in pomanjkanje ustreznih geoprostorskih podatkov o javnih prostorih ter nesoglasja med glavnimi deležniki med ključnimi vzroki proučevanega problema. Predstavili sta tudi metodologijo za uvedbo obsežne, prosto dostopne interaktivne geoprostorske podatkovne zbirke kot platforme za strateško načrtovanje, oblikovanje, razvoj in vzdrževanje javnih mestnih prostorov.

Ključne besede: javni mestni prostori, Sarajevo, strateško načrtovanje, geoprostorska podatkovna zbirka, digitalno vzpostavljanje kraja 


\section{Uvod}

Topografija Sarajeva, mesta v ozki dolini, obdani z gorami na severu in jugu, je omejevala njegovo širjenje in vplivala na njegovo morfologijo. Poleg tega zaradi zgodovinskih in kulturnih dejavnikov strateški razvoj večjih trgov, parkov in drugih javnih prostorov v preteklosti ni bil deležen ustrezne pozornosti v diskurzu, praksi in aktivizmu javnosti. Današnje mesto je upravna enota kantona Sarajevo in se razteza na površini $142 \mathrm{~km}^{2}$. Ima približno 413.593 prebivalcev in je razdeljeno na štiri občine: Stari Grad, Centar, Novo Sarajevo in Novi Grad.

Arhitekturna podoba današnjega Sarajeva je posledica njegove bogate in zapletene zgodovine (slika 1), pri čemer tipologija javnih prostorov in arhitekture kaže pretekle politične in ideološke sisteme (slika 2). Na verskih stavbah so opazne sledi turškega obdobja, mestne palače in stavbni bloki izhajajo iz obdobja Avstro-Ogrske, kulturni in športni objekti simbolizirajo ideologijo komunistične Jugoslavije, nakupovalna središča pa so postala templji sodobne družbe (Zagora in Šamić, 2014).

Zaradi temeljitih političnih in družbenoekonomskih sprememb v 90. letih 20. stoletja so bile pri zasebnih gradbenih projektih in preobrazbah $\mathrm{v}$ mestu njegove skupne vrednote večinoma prezrte. Identiteta današnjega Sarajeva je povezana zlasti z gradnjo po vojni v 90. letih, ki je večinoma brezbrižna do različnih zgodovinskih plasti mesta, nima splošne strategije in ne upošteva krajevnih posebnosti, kar povzroča vrzeli v urbani obliki (Husukić in Zejnilović, 2017). Podobno je značilno za vse države na Zahodnem Balkanu. Predstavniki neoliberalnih gospodarskih in političnih sil v postsocialističnih državah so si javne dobrine prilastili izključno v zasebno korist. Kot navaja Seferagićeva, so pobudniki opisanih družbenih sprememb, ki se kažejo v javnem prostoru, neoliberalni gospodarski akterji, za katere se včasih uporablja tujka nouveau-riche (novodobni bogataši) ali izraz tajkuni. V nasprotju s tajkuni 19. stoletja, ki so s financiranjem parkov, muzejev, gledališč

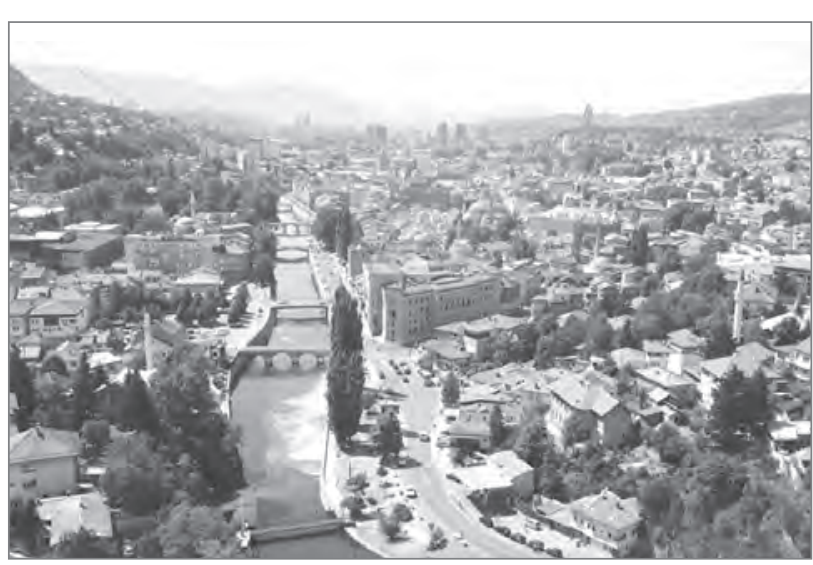

Slika 1: Zračni posnetek Sarajeva, ki prikazuje njegovo topografijo, urbano morfologijo in kulturno zgodovino (vir: Internet 2)
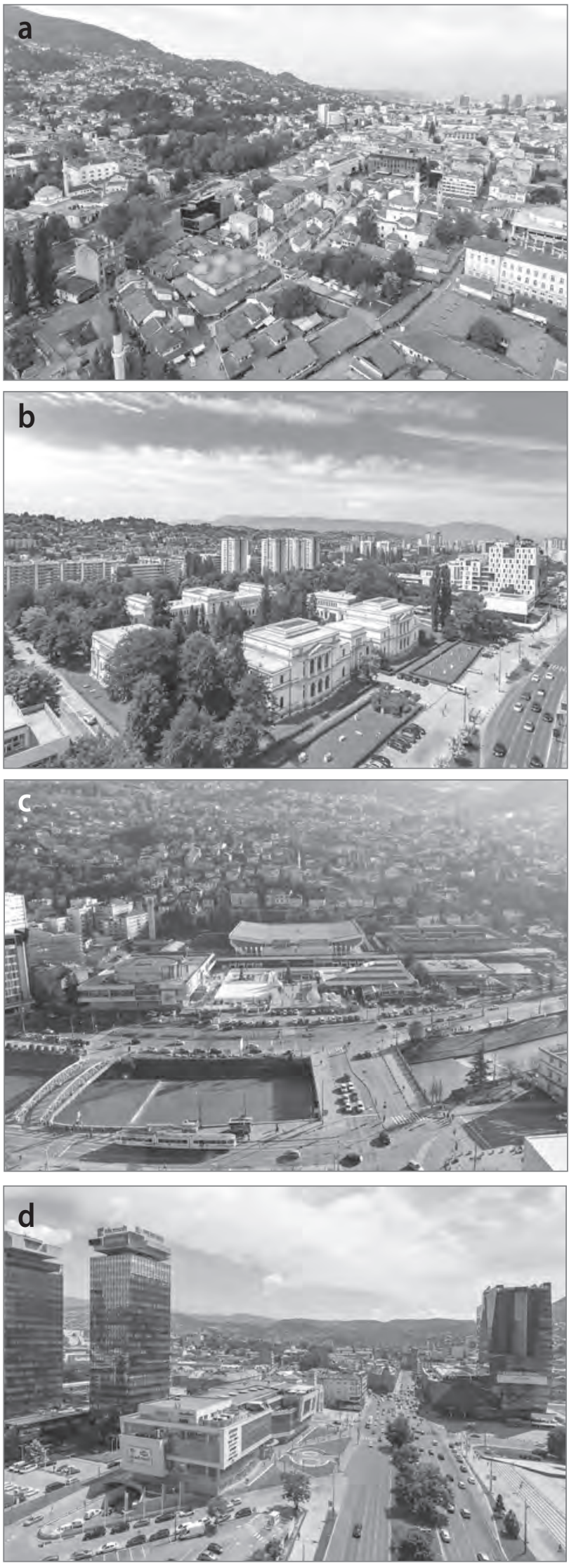

Slika 2: a) verske stavbe (vir: Internet 2), b) javne stavbe in mestna infrastruktura (vir: Internet 2), c) kulturna in športna središča (vir: Internet 3), d) nakupovalna središča (vir: Internet 2) 
itd. spodbujali razvoj civilne družbe in kulturnega dogajanja, nove gospodarske elite zanima samo privatizacija in pogosto tudi uničevanje skupnih javnih prostorov (Seferagić, 2007). Vzporedni ukrepi in procesi so povzročili podobne rezultate v urbanem okolju mnogih postsocialističnih mest, kot so Beograd, Zagreb in Budimpešta. Prehod od načrtovanja od zgoraj navzdol, značilnega za socialistično obdobje, h kapitalizmu je potekal nekritično in nenadzorovano, kar je povzročilo gostejšo pozidavo na središčnih območjih, negativne posledice gentrifikacije, komercializacijo in homogenizacijo mestnega okolja ter zanemarljivo vključenost prebivalcev. Vsem postsocialističnim mestom je skupno tudi neujemanje načrtov in zazidave v urbanem okolju, pri čemer načrti pogosto samo formalno upoštevajo javni interes, dejanske gradnje pa sploh ni (Zlatar Gamberozić, 2019). Opisani prehod ni vplival samo na povojno, postsocialistično in postmoderno družbo, ampak je pustil tudi prostorske sledi ter prispeval h krizi javnih prostorov v Sarajevu. Navedena kriza se nanaša na današnje propadanje mnogih javnih prostorov, njihovo nejasno programsko vsebino in lastništvo, slabo dostopnost, nepovezanost $\mathrm{z}$ okolico in odtujenost od lokalne skupnosti. Ker ni strateškega pristopa ali vizije, so sarajevski javni prostori v nekakšnem negotovem prehodnem položaju, v katerem so pasivno ujeti med preteklostjo, sedanjostjo in prihodnostjo ter nepovezani z okolico. Da bi javni prostori v Sarajevu spet postali pomembna tema za lokalne oblasti, raziskovalce, strokovnjake in javnost, sta avtorici v članku predstavili metodologijo in orodja, $s$ katerimi bi lahko pospešili sistematično urejanje in vzdrževanje skupnih prostorov v mestu.

\section{Osredotočenost na javne prostore}

Avtorici sta analizirali javne prostore v Sarajevu, določili ključne težave in predlagali inovativne možnosti izboljšanja navedenih javnih prostorov. Zaradi globalizacije in tehnoloških sprememb se je klasična idealistična predstava o teh prostorih kot demokratičnih odprtih prostorih, dostopnih vsem, v zadnjih desetletjih spremenila. Nekateri teoretiki trdijo, da komercializacija krni sámo javnost javnih prostorov in da spremljamo njihovo izgubljanje (Sorkin, 1992; Zukin, 1995; Koolhaas, 1997; Putnam, 2001; Sennett, 2002), drugi pa opisano preobrazbo obravnavajo samo kot fazo v njihovem razvoju (Loukaitou-Sideris in Banerjee, 1998; Carr idr., 1992). Avtorici ne predlagata nove definicije, ampak se na podlagi teoretičnega vpogleda v različne tipologije (Carr idr., 1992; Carmona, 2010) osredotočata na naslednje ključne značilnosti javnih prostorov: funkcijo/tipologijo, velikost, stopnjo odprtosti, dostopnost in urbano vzdušje.

Članek je razdeljen na štiri dele. Uvodu ter predstavitvi raziskovalnih ciljev, metodologije in hipoteze v poglavju Osre-
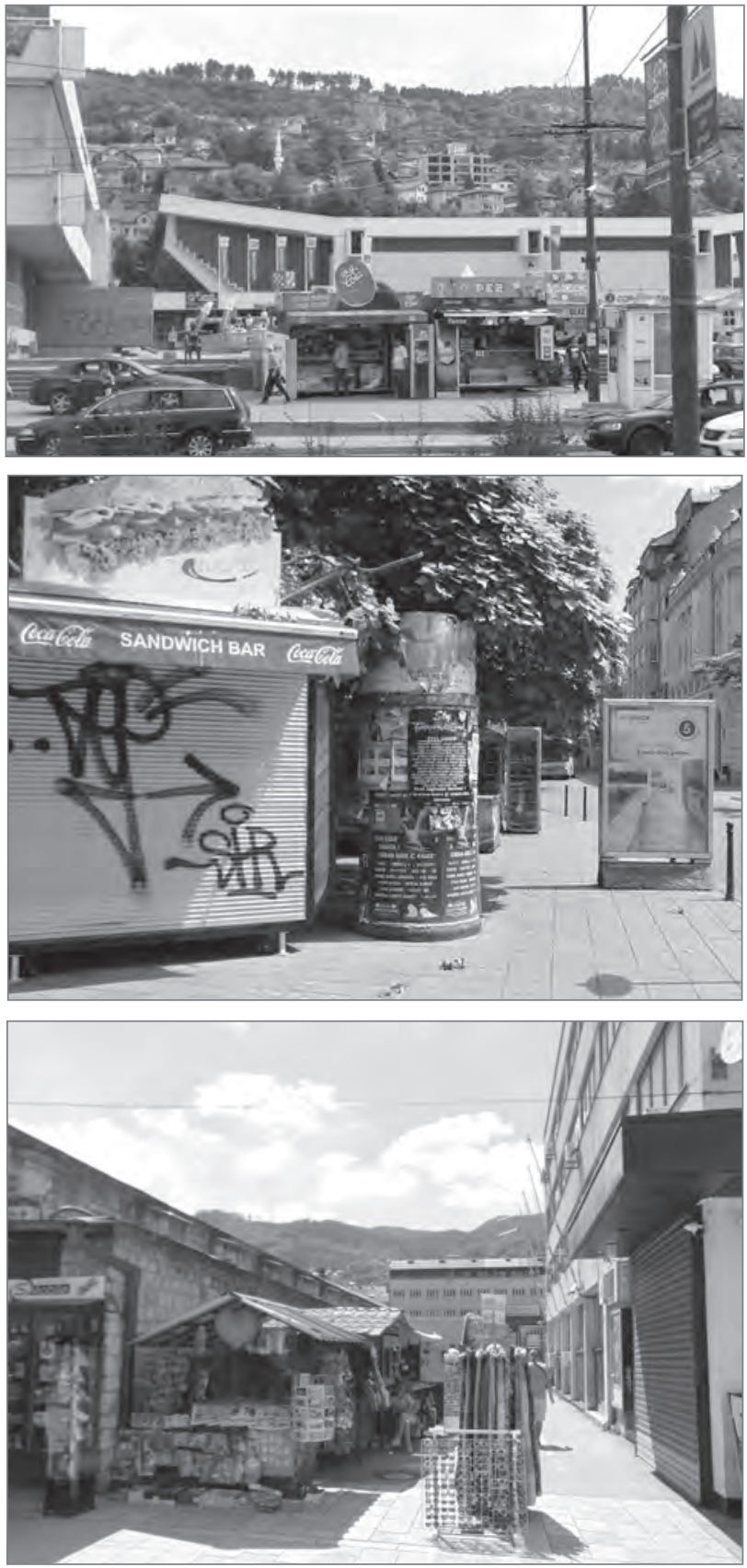

Slika 3: Primeri zasebnega prilaščanja in zanemarjanja javnih prostorov: ovire na sarajevskih ulicah in trgih (foto: avtorici)

dotočenost na javne prostore sledi podpoglavje z naslovom Trenutno stanje, v katerem so opisani ključni gospodarski, politični, ideološki, tehnični in organizacijski dejavniki, zaradi katerih javni prostori v Sarajevu propadajo. V tretjem poglavju avtorici analizirata najrazličnejše referenčne primere geoprostorskih podatkovnih zbirk javnih prostorov in pozitivne mednarodne prakse s področja združevanja urbanističnega načrtovanja in informacijskih tehnologij. $\mathrm{V}$ četrtem poglavju predstavita metodologijo oblikovanja digitalne platforme, pojasnita vloge potencialnih deležnikov in opišeta analitične zmogljivosti tovrstnega digitalnega orodja na primeru izbranih 
javnih prostorov v Sarajevu. Njuna raziskava temelji na predpostavki, da sta razpoložljivost in prost dostop do informacij med ključnimi temeljnimi pogoji za razvoj odprtih javnih prostorov. Večina ugotovljenih urbanističnih težav v Sarajevu je posredna ali neposredna posledica razpršenosti informacij in ustreznih podatkov o zgodovini, lastništvu, dostopnosti, funkciji, upravljanju, fizičnem stanju in okolici javnih prostorov. Avtorici sta postavili hipotezo, da lahko tehnološki napredek in razvoj digitalnih medijev okrepita sodelovanje med strokovnjaki, javnim in zasebnim sektorjem ter lokalno skupnostjo, in sicer z vzpostavitvijo odprte, demokratične in celovite platforme, ki se osredotoča na vizijo, razvoj in upravljanje javnih mestnih prostorov. $\mathrm{Z}$ uporabo tovrstne metodologije in drugih orodij digitalnega vzpostavljanja kraja se lahko izboljša kakovost obstoječih javnih prostorov in se prenovijo urbane praznine (ang. urban voids) v Sarajevu.

\subsection{Trenutno stanje}

Zaradi družbenih, političnih in gospodarskih sprememb na prelomu tisočletja so bile javna sfera in skupne vrednote postavljene pred preizkušnjo, javne pobude pa potisnjene v ozadje (Ibelings, 2010). Javni mestni prostori so posledično ostali na robu teorije, kritike, prakse in civilne angažiranosti. Med težavami, ki se vztrajno ponavljajo, so zasebno prilaščanje javnih prostorov, nejasno lastništvo, slaba dostopnost, neustrezno vzdrževanje in zanemarjenost, nedelovanje in razdrobljenost ter nepovezanost z urbano okolico ali skupnostjo (slika 3). V skladu z zgodovinskim in družbenopolitičnim ozadjem sarajevskih javnih prostorov lahko njihov trenutni položaj opišemo kot nestabilen in prehoden (Zagora in Samić, 2021). Podobno so tudi mestni prebivalci in ustanove potisnjeni $\mathrm{v}$ nekakšen vmesni položaj, v katerem so ujeti med spomini na daljno in bližnjo preteklost, med sedanjostjo in pričakovano prihodnostjo (Harrington idr., 2017).

V zadnjih letih so se nekateri lokalni upravni organi začeli zavedati pomena zagotavljanja javnih in skupnostnih prostorov, zaradi česar je opazen pojav ad hoc posegov v javni prostor, pri čemer se nekateri izvajajo brez posvetovanja s strokovnjaki in javnostjo, razpisov ali razprav (slika 4). Številni posegi so bili tako narejeni brez predhodne strategije ali povezave z lokalnim okoljem ter zato večinoma ostajajo nekakšni spomeniki političnim osebnostim ali sistemom in so brez pravega namena. Po drugi strani si lokalne skupnosti želijo manjše uporabne posege $\mathrm{v}$ javni prostor, kot so igrišča za različne starostne skupine in infrastruktura za starejše. Zdi pa se, da ni učinkovitih komunikacijskih kanalov, po katerih bi se njihova mnenja sporočala načrtovalcem, občinam, mestni upravi in upravi kantona.

V zadnjem desetletju sarajevske občine objavljajo razpise za ureditev izbranih javnih prostorov, kot so manjši trgi in par-
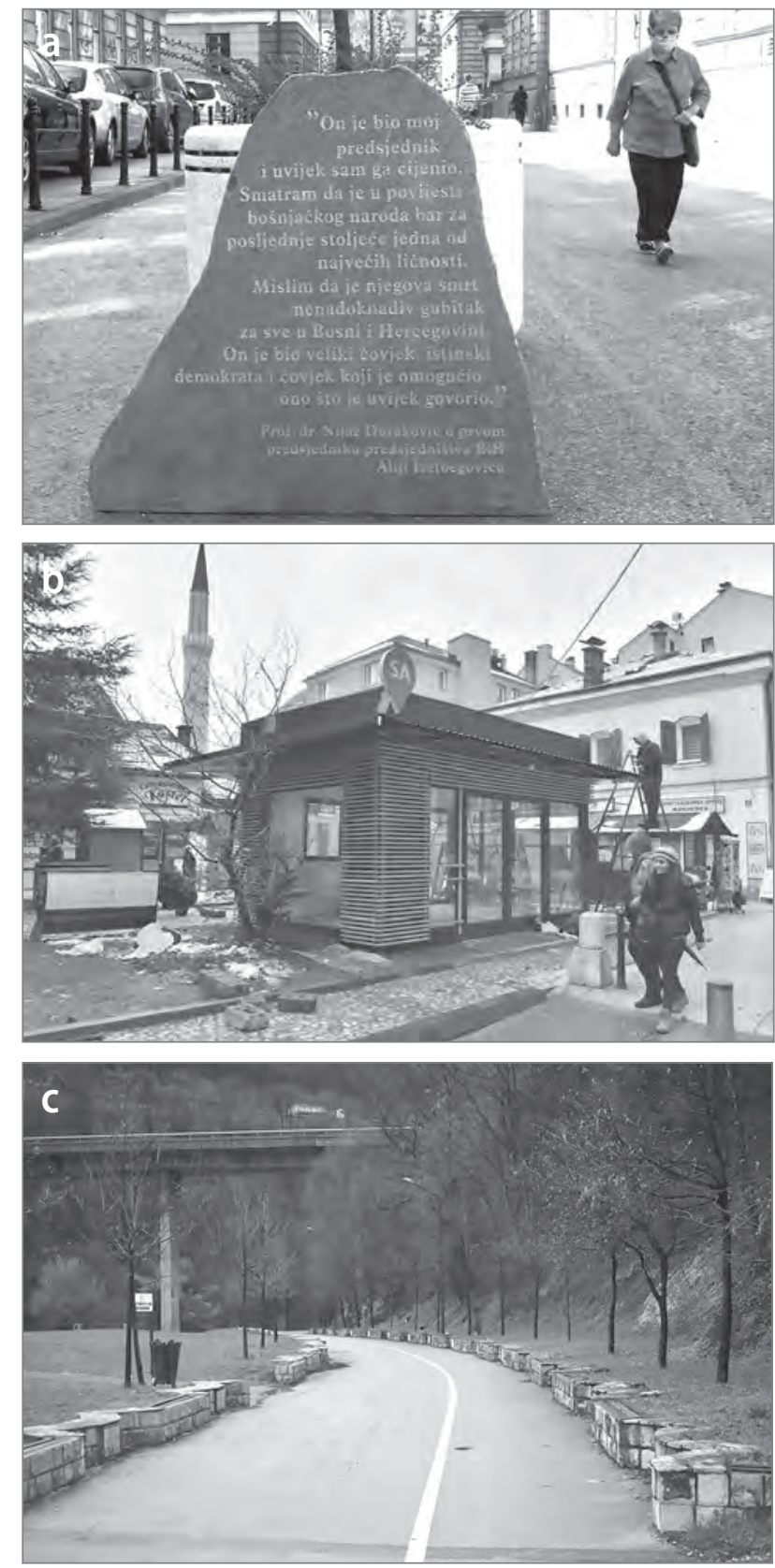

Slika 4: a) monoliti, raztreseni po ulici brez kakršnega koli logičnega zaporedja in povezave z okolico (vir: Općina Centar Sarajevo, 2021), b) turistični kiosk, ki ni bil nikoli odprt, prebivalci pa so se pritoževali nad predragimi stroški njegove postavitve (vir: Klix, 2021), c) sprehajališče brez jasne programske vsebine, prepoznavne estetike ali urbanega vzdušja (vir: Općina Stari Grad Sarajevo, 2021)

ki, a večinoma samo za oblikovanje spomenikov žrtvam vojne v Bosni in Hercegovini v 90. letih prejšnjega stoletja. Zaradi razpisnih postopkov se večina oblikovalskih projektov, ki na razpisih zmagajo, sploh ne dokonča ali je izvedena samo delno, brez posvetovanja z avtorji projekta. Večina razpisov se osredotoča na oblikovanje spomenikov in obeležij, iskanje rešitev za urejanje javnega prostora pa je drugotnega pomena. Leta 2020 je bil na primer objavljen razpis za oblikovanje spomenika na 
eni najpomembnejših lokacij v Sarajevu - Trgu Alije Izetbegovića. Zmagovalni oblikovalski projekti nikoli niso bili javno predstavljeni, ko pa je občina pred kratkim napovedala gradnjo podzemnega parkirišča, je to spodbudilo javno razpravo. Opisano kaže na pomanjkanje strateškega pristopa in usklajenosti procesov in ukrepov, predvidenih na izbrani lokaciji. $\mathrm{Na}$ področju urejanja javnih mestnih prostorov v državi se je v Sarajevu in Banjaluki v zadnjem desetletju začelo kar nekaj odmevnih neinstitucionalnih pobud. Leta 2013 sta kulturno društvo Crvena in prostorska pobuda LIFT začela izvajati projekt Gradology project, ki je pravzaprav spletna aktivistična platforma, s katero lahko Sarajevčani odkrivajo javne prostore, kot so parki, trgi, zapuščene stavbe in neuporabljeni prostori, in jih označijo na zemljevidu (LIFT, 2015). Druga skupina aktivistov, znana pod imenom Dobre Kote (Dobri kotički), je od leta 2015 izvedla več neformalnih projektov urbanih posegov v prostor, s katerimi so bili zapuščeni mestni kotički spremenjeni v kraje, ki jih lokalna skupnost uporablja za druženje. Nekaj primerov uporabe izrazitega pristopa od spodaj navzgor pri ponovni aktivaciji javnih prostorov lahko zunaj Sarajeva najdemo v Banjaluki, kjer skupina strokovnjakov in aktivistov v projektni skupini Small SCALE pri Centru za prostorske raziskave organizira delavnice ter oblikuje in izvaja manjše prostorske posege v mestu (Karan idr., 2017).

Avtorici sta navdih za naslov članka dobili pri Lefebvrovemu konceptu pravice do mesta iz leta 1968 (Lefebvre, 1968). Osredotočili sta se na problematiko javnih prostorov z vidika pravic in dolžnosti ter določili ključne deležnike: kdo je lastnik javnih prostorov v Sarajevu, kdo ima dostop do njih ter kdo jih oblikuje, vzdržuje, uporablja, aktivira in spreminja. Zaradi prevlade zasebnih interesov nad javnimi v novejši zgodovini mesta imajo njegovi prebivalci popačeno predstavo o njegovi dediščini in čutijo odpor do zapuščine socialističnega obdobja, opazno pa je tudi razhajanje med individualnim in kolektivnim (Zagora in Samić, 2021). Ker spominjajo na socialistično ideologijo kolektivnih vrednot, so se nekateri javni prostori celo spremenili v siva območja mesta ali urbane praznine (de Sola Morales, 2003), njihova ureditev pa v uradnih prostorskih aktih ne spada med prednostne naloge. Na podlagi ugotovljenih problemov zanemarjenosti, razdrobljenosti in zasebnega prilaščanja javnih prostorov avtorici proučujeta temeljne pogoje za oblikovanje strateškega pristopa $\mathrm{k}$ načrtovanju, oblikovanju, razvoju in vzdrževanju skupnih prostorov, ki bi temeljil na sodelovanju vseh deležnikov, določanju odgovornosti in ozaveščanju splošne javnosti.

\section{Metodologija in analiza}

\subsection{Geoprostorska podatkovna zbirka javnih prostorov}

Čedalje večja urbanizacija in neupoštevanje javnih prostorov sta pereč problem na globalni ravni, zato je eden izmed ciljev trajnostnega razvoja, ki so jih določili Združeni narodi in naj bi bili doseženi do leta 2030, tudi zagotoviti splošen dostop do varnih, odprtih in dostopnih zelenih in javnih površin, zlasti za ženske in otroke, starejše in invalide. $\mathrm{V}$ ta namen so bila $\mathrm{v}$ okviru Programa Združenih narodov za naselja (UN-Habitat, 2018) izdana priporočila glede zaželenega deleža mestnih zemljišč, namenjenih odprtim javnim prostorom, pri čemer naj bi bilo 45-50\% zemljišč dodeljenih ulicam in pločnikom, 15-20 \% pa javnim odprtim prostorom. Oblikovalci politik, voditelji, prebivalci in urbanisti pogosto zanemarjajo ali podcenjujejo pomen javnih prostorov. Za to je več razlogov, na primer pomanjkanje virov in nezadostno razumevanje ali nezmožnost uporabe javnih prostorov kot zaokroženega večfunkcionalnega urbanega sistema. Pogosto razmere še poslabšajo dejavniki, kot so pomanjkanje ustreznih spodbujevalnih okvirjev, šibka politična volja in to, da ni ustreznih načinov vključevanja javnosti. Dejansko pa pomen javnih prostorov na lokalni in svetovni ravni ni bil prepoznan predvsem zato, ker ni globalnega kazalnika na tem področju (United Nations Statistics Division, 2020).

UN-Habitat med načrtovalskimi in upravljavskimi pristopi lokalnim upravam predlaga sistemski pristop, ki vključuje zbiranje točnih, pravočasnih ter razdruženih podatkov in informacij. Zbiranje podatkov večinoma temelji na satelitskih posnetkih (iz prosto dostopnih virov), dokumentaciji o zemljiščih $\mathrm{v}$ javni lasti in zemljevidih lokalne skupnosti. Pomemben korak naprej, ki ga predlaga UN-Habitat, je uporaba metodologije kartiranja razpoložljivih in potencialnih javnih prostorov po vsem svetu. Na podoben način je na primer Inštitut Jana Gehla skupaj $s$ partnerji (mestnima občinama København in San Francisco ter seattelskim občinskim uradom za promet) razvil poseben protokol za zbiranje podatkov o življenju na javnih prostorih z naslovom Public Life Data Protocol (Gehl Architects, 2020). Protokol je prosto dostopen, njegov namen pa je omogočiti celovitejše in bolj usklajeno zbiranje prostorskih podatkov po urbanističnih uradih po vsem svetu. Predlaga različne ankete in orodja, ki so preprosta za izvedbo, na primer štetje ljudi, ki se premikajo po javnem prostoru, ali kartiranje dejavnosti na javnem prostoru, pri katerih se ljudje ne premikajo. Podobno je tudi ekipa KTH pod vodstvom Sethe Low ustvarila projekt Public Space Database Project (Centre for the Future of Places, 2020), katerega namen je zbiranje raziskovalnih podatkov z različnih področij in njihovo združevanje v podatkovno 


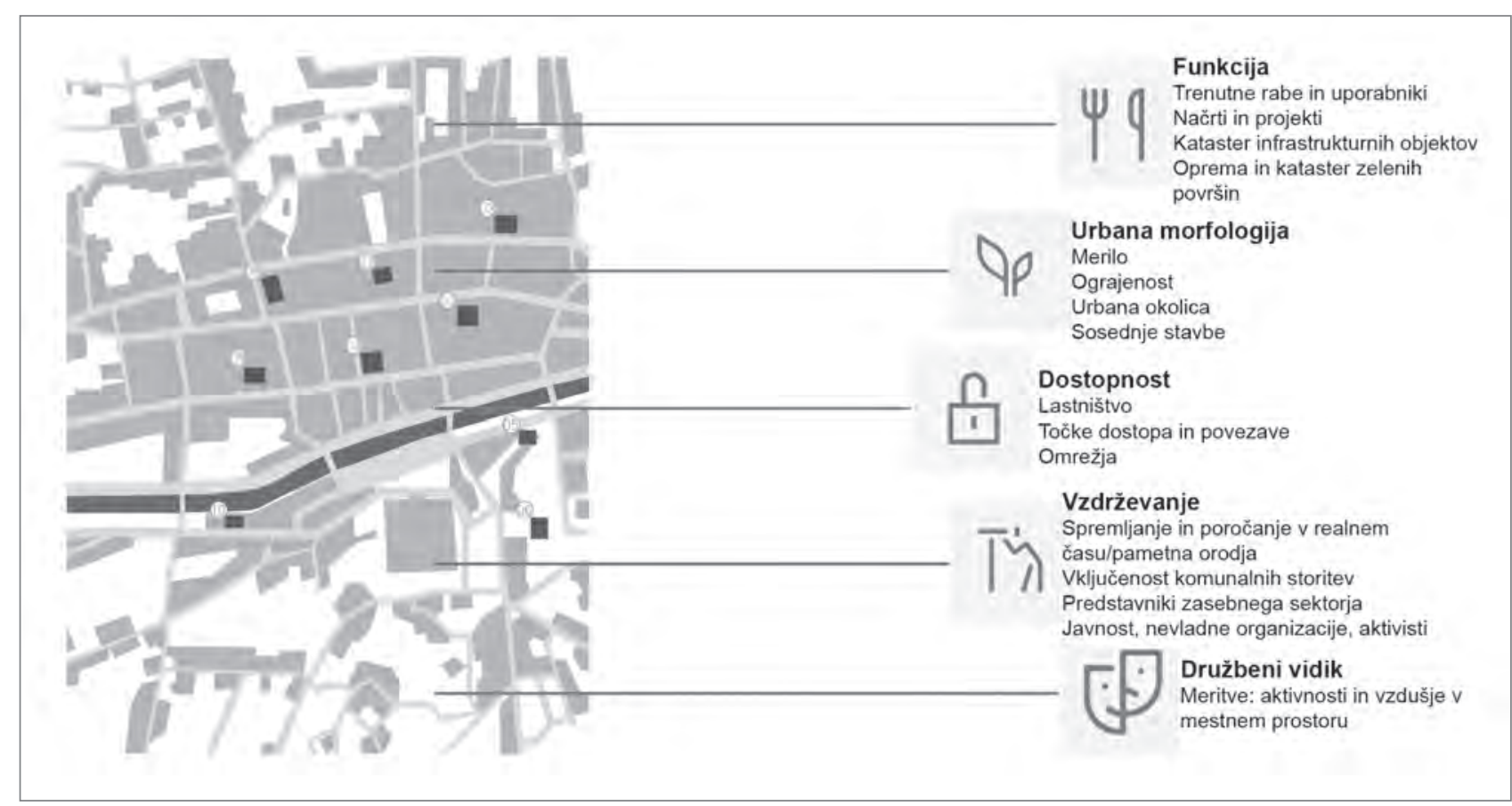

Slika 5: Sestava interaktivne digitalne platforme za javne prostore v Sarajevu (ilustracija: avtorici)

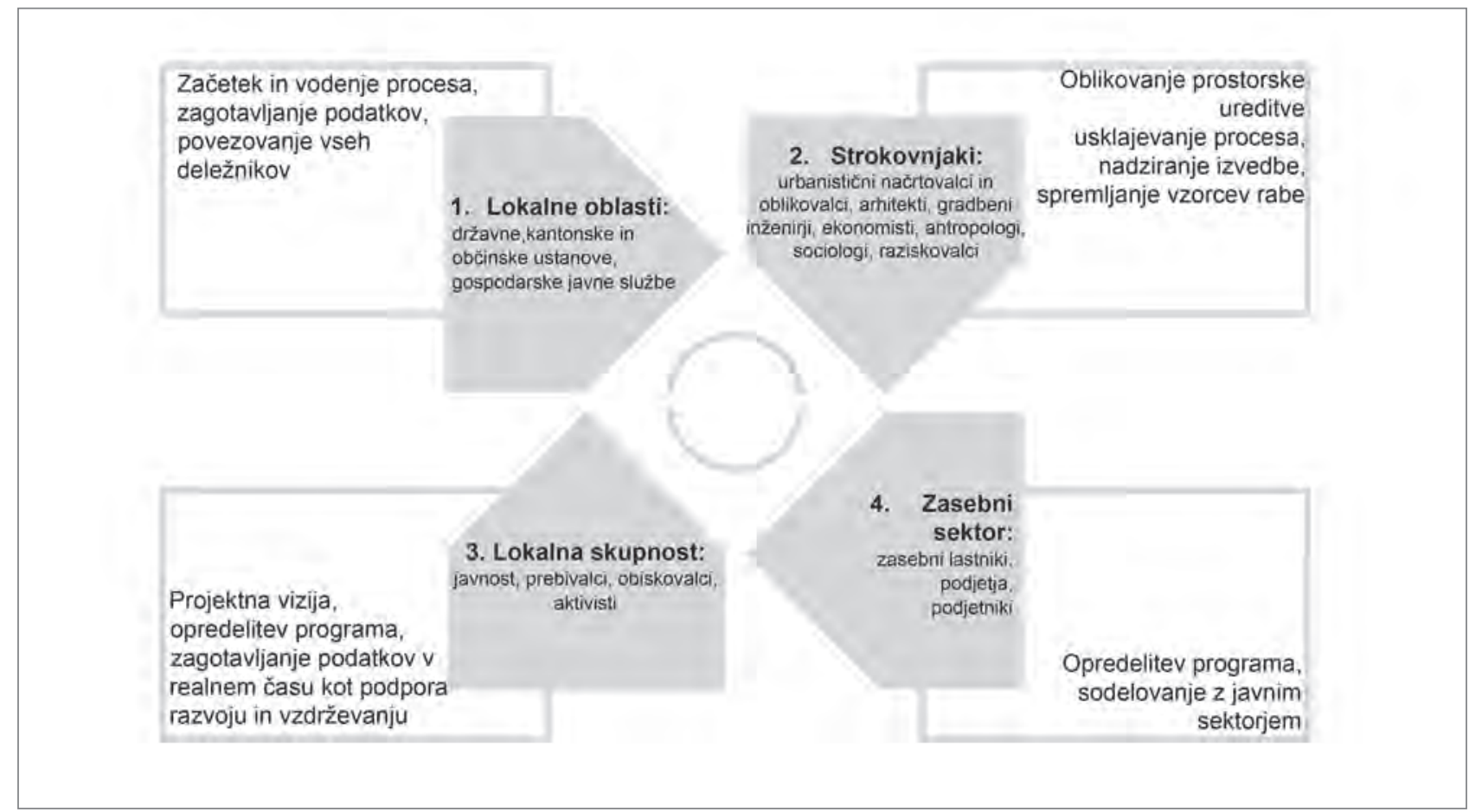

Slika 6: Potencialne skupine uporabnikov prosto dostopne podatkovne zbirke javnih prostorov v Sarajevu (ilustracija: avtorici)

zbirko, ki temelji na uporabi splošne terminologije ter je dostopna in razumljiva vsem.

Na podlagi predstavljenih primerov je jasno, da sta temeljna pogoja za zagotavljanje bolj trajnostnih in vključujočih javnih prostorov multidisciplinarni pristop in dostop do vseh poglavitnih podatkov. Za kakovostnejše javne prostore v Sarajevu bi bilo torej treba najprej oblikovati okvir za razvrstitev javnih mestnih prostorov, ki bi vključeval več plasti informacij ali metapodatkov v realnem času, kot so podatki o zgodovini, funkciji (hibridnosti), lastništvu, upravljanju, infrastrukturi, sosednjih objektih in prostorih, sodelujočih deležnikih in rezultatih meritev (npr. vzorcih uporabe in delovanja javnih prostorov), hkrati pa bi omogočal spremljanje stanja vzdrževanosti ter poročanje o tehničnih in varnostnih zadevah, kar bi spodbujalo vključevanje javnosti (slika 5). 
Preglednica 1: Kriteriji, na podlagi katerih so bili kartirani javni prostori v Sarajevu

\begin{tabular}{ll}
\hline Kriterij & Atributi \\
\hline Tipologija & Zeleni, mestni, skupnostni, prometni, javni notranji prostori, neopredeljeni \\
\hline Velikost & Veliki in zelo veliki, srednje veliki, majhni in zelo majhni \\
\hline Stopnja odprtosti & Odprti, polodprti, zaprti \\
\hline Aktivnost & Aktivni in sezonsko aktivni, pasivni \\
\hline Dostopnost & Dostopni, pogojno dostopni \\
\hline Urbano vzdušje & Ekstrovertirani, introvertirani \\
\hline
\end{tabular}

V tovrstni obsežni prostodostopni podatkovni zbirki bi bili zbrani vsi pomembni podatki najrazličnejših ustanov in deležnikov, od občinskih uradov, urbanističnih inštitutov, svetov krajevnih skupnosti in nevladnih organizacij do aktivističnih skupin, ki se ukvarjajo s problematiko javnih prostorov. Zbrani podatki bi bili sistematično razvrščeni na podlagi tipoloških meril ( $\mathrm{v}$ funkcionalne, prostorske in družbene podatke), nato pa bi bili razdeljeni v različne plasti, s prekrivanjem katerih bi lahko bolje razumeli izbrano območje. Poleg tega bi morala podatkovna zbirka delovati kot interaktivna platforma, ki bi bila namenjena zbiranju in deljenju podatkov. Ena najpomembnejših koristi takih digitalnih orodij je ta, da lahko zagotavljajo edinstveno zbirališče za vse deležnike, ki želijo ustvarjati boljše javne prostore. Pri tem je treba združiti štiri ključne deležnike, katerih sodelovanje je odločilno za prihodnost javnih prostorov: gospodarski sektor (industrijo, lastnike zemljišč in banke), politiko (politične voditelje in stranke), strokovnjake s področja prostorskega razvoja (urbaniste, arhitekte in inženirje) in civilno družbo (javnost, nevladne organizacije in urbana družbena gibanja) (Seferagić, 2007). Opisana prosto dostopna platforma bi spodbujala in krepila vključevanje javnosti, družbeno kohezijo in zaupanje v skupnost - vrednote, za katere se zdi, da so v postranzicijski družbi že dolgo pozabljene.

Vključenost javnosti ne bo povzročila samo demokratizacije vseh procesov, povezanih s prostorom, ampak bo spremenila tudi trenutno mišljenje ljudi. Pomembno je poudariti, da bi moralo sodelovanje lokalne skupnosti pri odločanju prek digitalnih orodij presegati formalno raven, glas ljudstva pa bi moral biti upoštevan že od vsega začetka. $V$ prihodnje je zato zelo pomembno, da je javnost vključena že v začetne faze prostorskega načrtovanja, saj je ključni akter kakršne koli urbane revitalizacije mesta (Zlatar Gamberožić, 2019). Prostore, ki ne pripadajo nikomur, lahko tako končno zamenjajo prostori, $k i$ pripadajo vsem. Zbrani podatki bi bili v opisanem postopku pretvorjeni v orodje, ki bi lokalne oblasti usmerjalo pri načrtovanju in izvajanju prostorskih posegov. Poleg tega bi omogočalo spremljanje stanja javnih prostorov in urbane opreme $\mathrm{v}$ realnem času.

Zavedati pa se je treba, da bi imela tovrstna platforma različne uporabnike, od urbanistov, arhitektov, raziskovalcev, investitorjev in drugih strokovnjakov do zasebnih vlagateljev, komunalnih služb in skladov, nevladnih organizacij, aktivistov, javnosti in turistov, med katerimi bi vsak iskal in delil različne vrste podatkov (slika 6). Zato je zelo pomembno, da se uporablja splošna terminologija, čeprav bo platforma razdeljena na številne odseke glede na zahteve, znanje in spretnosti uporabnikov.

\subsection{Kartiranje javnih mestnih prostorov}

Avtorici sta javne prostore v Sarajevu kartirali, da bi dobili splošen vpogled v to, kako so porazdeljeni. Kartiranje je temeljilo na uporabi izbranih kriterijev, ki opredeljujejo naravo javnih prostorov, vključno z njihovo tipologijo, velikostjo, stopnjo odprtosti, aktivnostjo, dostopnostjo in urbanim vzdušjem (preglednica 1).

Podoben metodološki pristop se lahko uporabi za oblikovanje interaktivne podatkovne zbirke javnih prostorov v Sarajevu. Posledična geoprostorska platforma bi omogočala združevanje, prekrivanje ali razstavljanje številnih podatkovnih slojev, na podlagi česar bi bila prikazana porazdeljenost javnih prostorov v mestu ali pa predstavljena povezava med vsemi prostorskimi in družbenimi vidiki izbranega območja.

Pri kartiranju je bil vsak javni prostor na podlagi vnaprej opredeljenih kriterijev povezan $s$ točno določenim prostorskim ali družbenim atributom. Ključno je bilo torej zbrati vse razpoložljive geoprostorske podatke in jih povezati s proučevanim zemljiščem in uradnimi prostorskimi akti. Kartiranje je bilo tako uporabljeno kot metodološko raziskovalno orodje za klasifikacijo javnih prostorov v Sarajevu. Razvoj digitalne geoprostorske platforme ali podatkovne zbirke lahko temelji na vnaprej določenih kriterijih kartiranja javnih prostorov, podatkovni sloji pa se lahko naknadno združijo v kategorije, med seboj prekrijejo ali pa seštejejo z ukazom » presek «. Kriteriji, ki se lahko uporabljajo pri kartiranju in so predstavljeni v nadaljevanju, so: funkcija in dostopnost, urbana morfologija in družbeni vidik. Po razlagi vsake skupine kriterijev je predstavljena simulacija funkcionalnosti potencialne digitalne platforme, in sicer $s$ prikazom zemljevidov ali kartografskih izsekov štirih izbranih lokacij v mestu. 


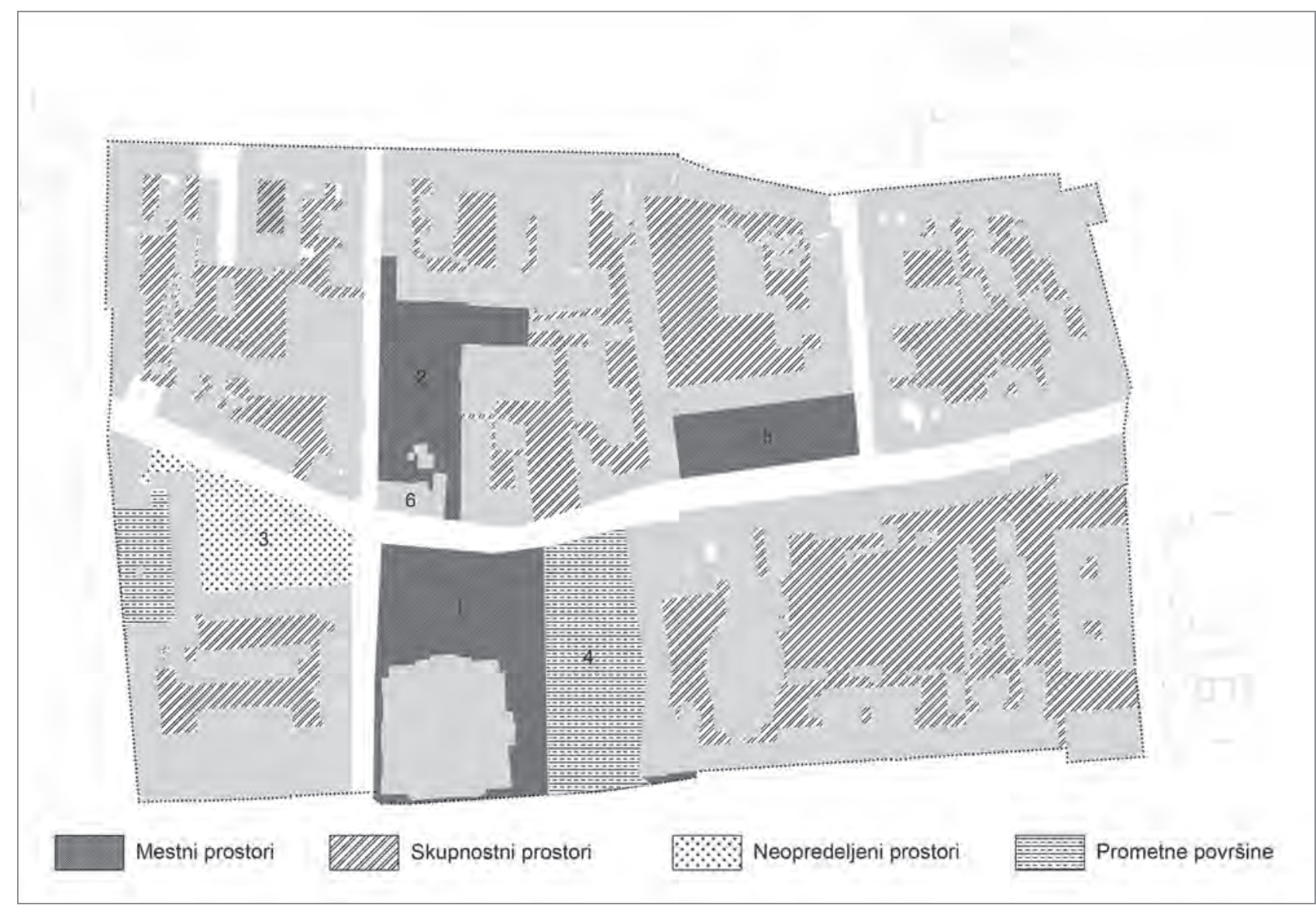

Slika 7: Kartiranje središča Sarajeva: 1. gledališki trg, 2. trg mladinskega gledališča, 3. arheološko najdišče, 4. parkirišče, 5. park in 6. prazna stavba (ilustracija: avtorici)

\section{Rezultati in razprava}

\subsection{Funkcija in dostopnost}

Funkcija in raba prostora sta temeljna kriterija za določanje vrst javnih prostorov. Z drugimi besedami, tipologijo javnih prostorov običajno določajo aktivnosti, ki jih navedeni prostori omogočajo in ustvarjajo. Javni prostori so že od nekdaj kraji, na katerih se ljudje družijo, in prizorišče kulturnih in političnih dogodkov. $V$ današnji družbi, v kateri se krepijo individualizem in družbeni mediji, je tradicionalna vloga javnih prostorov postavljena pred preizkušnjo. Kot navaja Gehl (2011), lahko aktivno navzočnost, sodelovanje in izkušnje zdaj nadomesti pasivno gledanje fotografij, ki prikazujejo, kaj so drugi doživeli nekje drugje. Avtomobil pa omogoča, da namesto aktivnega sodelovanja v spontanem lokalnem družabnem dogajanju raje obiščemo izbrane prijatelje in znamenitosti.

$\mathrm{Na}$ podlagi funkcionalnih razvrstitev javnih prostorov, ki so jih razvili Carr idr. (1992), Oldenburg (1997) in Carmona (2010), sta avtorici kartirali porazdeljenost šestih funkcionalnih vrst javnih prostorov v Sarajevu: zelenih, mestnih, skup- nostnih, prometnih, javnih notranjih prostorov, objektov in drugih krajev ter neopredeljenih prostorov. Fizična in psihološka dostopnost sta med najpomembnejšimi vidiki, ki določajo javnost mestnih prostorov. Dostopnost je poudarjena že v naslovu tega članka, nanaša pa se na upravičenost do uporabe javnih prostorov. Stopnja dostopnosti skupaj z lastništvom določa zasebnost ali javnost mestnih območij. $V$ današnjih mestih je meja med javnimi in zasebnimi prostori pogosto zabrisana. Navedenemu pojavu se pogosto očita, da povzroča erozijo javnih prostorov (Sennett, 2002), zgoraj opisano hibridizacijo prostorov pa lahko razumemo kot fazo v njihovem razvoju (de Solà Morales, 1992; Kohn, 2004). Glede na različno stopnjo dostopnosti sta avtorici s kartiranjem določili dve kategoriji sarajevskih javnih prostorov: dostopne in pogojno dostopne. Povezava med funkcijo in dostopnostjo je ključni del analize trenutnega položaja in potenciala javnih prostorov v mestu.

Glavna vloga digitalne platforme je torej zagotavljanje dostopa do podatkov o funkcijah, dostopnosti in lastništvu javnih prostorov, ki so temelj za nadaljnjo analizo njihovih morebitnih preobrazb. Poleg tega bi platforma omogočila boljši vpogled $\mathrm{v}$ širši mestni prostor in razmerje med vrstami javnih prostorov, razkrila možnosti za oblikovanje omrežij javnih prostorov, 


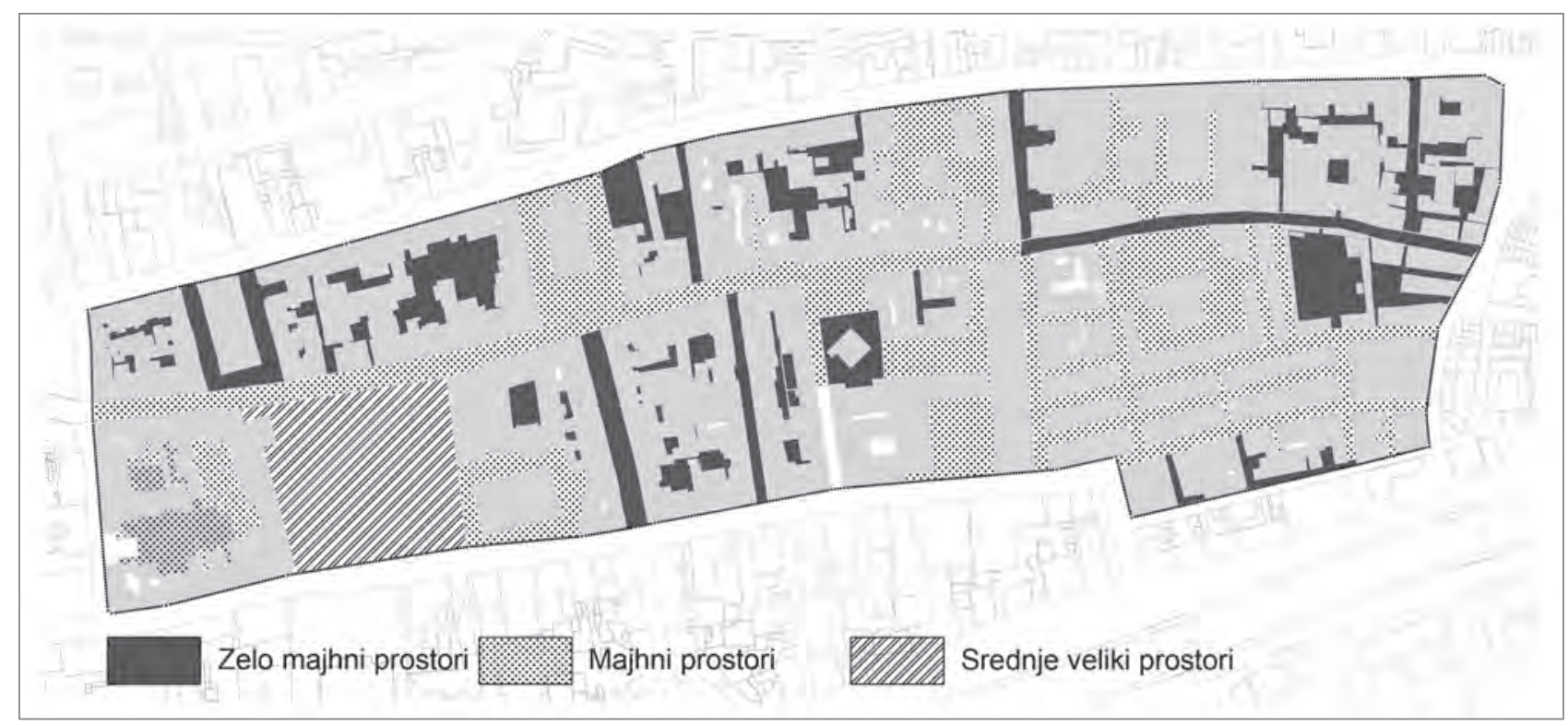

Slika 8: Kartiranje javnih prostorov v starem mestnem jedru Sarajevu glede na velikost (ilustracija: avtorici)

\subsection{Urbana morfologija}

sosednjih območij in objektov ter okrepila sodelovanje med vsemi deležniki. Kartiranje javnih prostorov v Sarajevu je na primer razkrilo heterogenost in hibridnost njihovih funkcij. Gledališki trg Susan Sontag (bos. Pozorišni trg - Susan Sontag) in Trg kulture Jurislava Korenića (bos. Trg kulture Jurislav Korenić) sta se izkazala za glavni kulturni območji, katerih funkcija pa še vedno ni dovolj jasno izražena (slika 7). Glavni gledališki trg obkrožajo tri razmeroma neaktivna javna območja z nejasno funkcionalnostjo in dostopnostjo: arheološko najdišče na zahodu, zasebno parkirišče na vzhodu in prazno hotelsko poslopje iz začetka 20. stoletja na severu. Zaradi dolgoletnih sporov se je arheološko najdišč z ostanki nekdanje džamije spremenilo v urbano praznino ali neopredeljen, nedostopen in zanemarjen prostor brez povezave z okolico, ki že dolga leta ostaja neurejen in zato propada. Drugi sosednji javni prostor, ki bi bil lahko ustrezno preurejen, je zasebno parkirišč proti vzhodu. Po poročanju več medijev je na tem območju že več desetletij predvidena gradnja podzemnega parkirišča. Če pa bi se preuredilo v območje za pešce, bi lahko kot podalǰ̌sk gledališkega trga odpiralo nov pogled na trg in z njega ter zagotavljajo prostor za številne aktivnosti. Opisana prostorska razdrobljenost, spori in različni vzorci rabe mestnih prostorov so posledica nejasne programske opredelitve in slabe dostopnosti proučevanega območja. Naštete težave bi lahko rešili in raznolike mestne prostore povezali v omrežje živahnih javnih prostorov $s$ sistematičnim in preglednim zbiranjem in kartiranjem vseh ustreznih podatkov, na podlagi česar bi se lahko nato načrtovala preobrazba celotnega območja.
Geometrijske in fizične lastnosti, kot so velikost, konfiguracija in tridimenzionalna oblika javnih prostorov, so pomembni vidiki vsakršne analize mestnih prostorov. V primeru Sarajeva je na morfologijo pozidanega okolja, tudi odprtih javnih prostorov, močno vplivala naravna topografija mesta. Zaradi hribov na severni in južni strani se je mesto širilo od vzhoda proti zahodu po dolini reke Miljacke. V zgodnji fazi razvoja (v srednjem veku in obdobju turške oblasti) je na urbano mrežo nezavedno vplivalo človeško merilo (ang. human scale), s čimer so bili oblikovani najrazličnejši intimni javni mestni prostori, opredeljeni v urbanistični teoriji (Lynch, 1971; Gehl, 2011). Od vzhoda proti zahodu se merilo postopno veča, pri čemer se dimenzije prostorov in stavb ujemajo $s$ kronološkim razvojem mesta v obdobjih Avstro-Ogrske, Kraljevine Jugoslavije in socialistične Jugoslavije (slika 8). S kartiranjem javnih prostorov na podlagi njihove morfologije sta avtorici določili tri kategorije javnih prostorov glede na njihovo velikost: velike in zelo velike, srednje velike ter majhne in zelo majhne javne prostore in površine. Še ena pomembna geometrijska lastnost javnih prostorov je njihova tridimenzionalna oblika. Čeprav se javni prostori že od nekdaj dojemajo kot prazne površine v prostoru, so dejansko del urbane mreže, v kateri jih določajo robovi, ploskve ter volumni okoliških stavb in stavbnih blokov. Glede na stopnjo odprtosti sta avtorici določili tri kategorije javnih prostorov v Sarajevu: odprte, zaprte in polodprte.

$\mathrm{V}$ predelih mesta, ki izvirajo iz turškega obdobja, prevladujejo intimni prostori v človeškem merilu, kot so zelo majhna in majhna notranja dvorišča in ulice. Dimenzije prostorov se nato proti zahodu večajo v skladu s kronološkim razvojem, in 


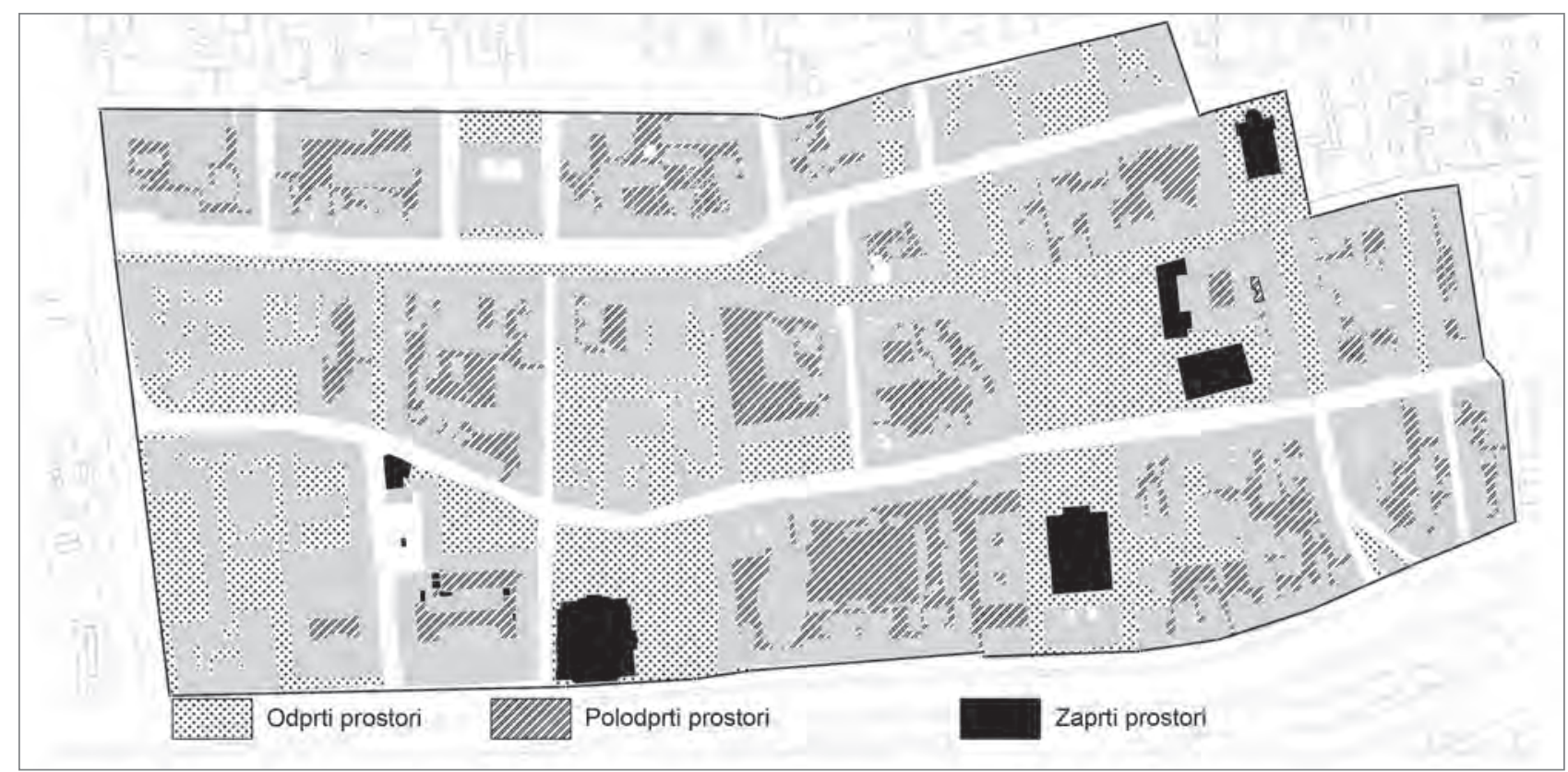

Slika 9: Kartiranje javnih prostorov v središču Sarajeva glede na stopnjo odprtosti (ilustracija: avtorici)

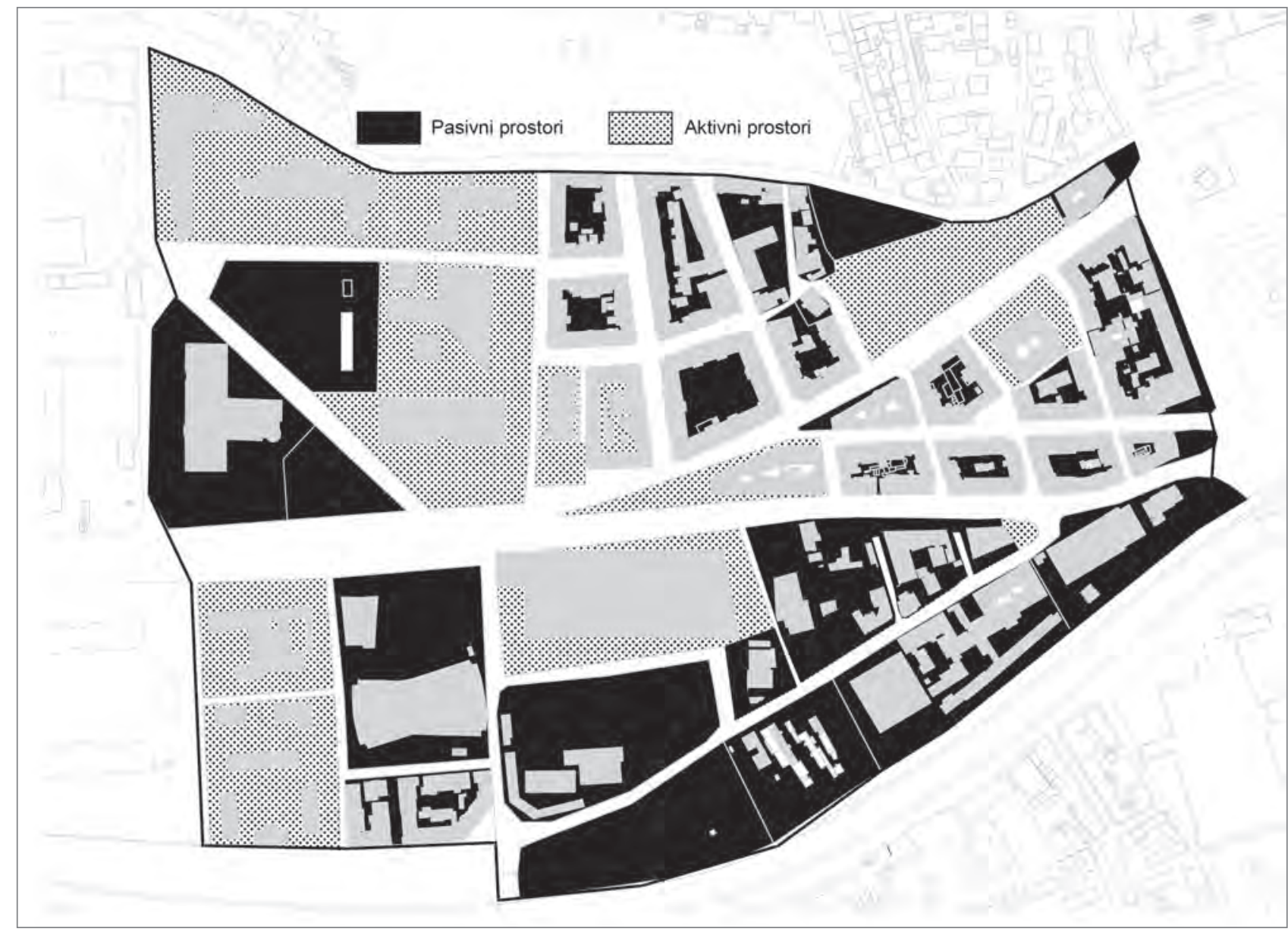

Slika 10: Kartiranje območja Marijinega dvora v Sarajevu (ilustracija: avtorici) 
sicer od srednje velikih javnih prostorov v soseskah iz obdobja Avstro-Ogrske in Kraljevine Jugoslavije do velikih javnih površin v soseskah iz socialističnih časov in sodobnega obdobja.

Kartiranje starega mestnega jedra in drugih predelov v središcu Sarajeva na podlagi morfologije je razkrilo posebne kategorije polodprtih majhnih do srednje velikih javnih prostorov (slika 8), ki se ujemajo z notranjimi dvorišči stavb iz turškega obdobja na Baščaršiji in atriji stavb iz obdobja Avstro-Ogrske. Funkcija in dostopnost nekaterih od teh prostorov sta nejasni in neopredeljeni, hkrati pa imajo velik potencial za preobrazbo, $s$ katero bi mesto lahko spet pridobilo dostopne javne prostore. $S$ sistematskim pristopom ter evidentiranjem, kartiranjem in povezovanjem vseh pomembnih podatkov, ki se nanašajo na opisano tipologijo prostorov, bi lahko oblikovali strategijo ponovne opredelitve in preobrazbe teh območij in njihove okolice.

\subsection{Družbeni vidik}

Največji teoretiki s področja urbanizma menijo, da so družbene aktivnosti, kakovost javnega življenja in urbano vzdušje ključne vrednote javnih prostorov (Carr idr., 1992; Varna in Tiesdell, 2010; Gehl, 2011). Poleg fizičnih lastnosti javne prostore določajo tudi njihova družbena vrednost ali vrste in ravni družbenih aktivnosti in interakcij, ki jih spodbujajo. Kot navajata Varna in Tiesdell (2010), javni prostor zagotavlja skupno podlago za družbeno interakcijo, druženje in sporazumevanje: je kraj družabnosti, izmenjave informacij, osebnega razvoja, družbenega učenja (tj. učenja o drugem) in razvijanja strpnosti. Gehl pa izpostavlja, da sta opazovanje na kraju samem in merjenje družbenih aktivnosti, kot so hoja, kolesarjenje, stoja, zadrževanje, sedenje, gledanje, poslušanje, govorjenje, igranje, telovadba in zabava, podlaga za izboljšanje in razvoj javnih prostorov (Gehl Institute, 2017). Z analizo aktivnosti na javnih prostorih v Sarajevu sta avtorici te prostore razdelili $\mathrm{v}$ dve kategoriji: aktivne in sezonsko aktivne javne prostore ter pasivne javne prostore. $S$ kartiranjem soseske Marijin dvor v središču mesta sta ugotovili, da so družbene aktivnosti na tamkajšnjih javnih prostorih neenakomerno razporejene (slika 10). V glavnem se zgoščajo okoli poslovnih in trgovskih objektov, območja okoli različnih ustanov, kot je parlament, in stavbnih blokov pa zaradi fizične in psihološke nedostopnosti ostajajo pasivna. Druga pasivna območja vključujejo urbane praznine ob reki Miljacki, na katerih naj bi se v prihodnje gradilo, in številne atrije stavb iz avstro-ogrskega obdobja, ki so le delno javno dostopni in nimajo jasnega lastništva. Po drugi strani so zaprtost in intimnost teh polodprtih javnih prostorov ter vzdušje na njih lahko prednost pri morebitnih projektih urbane preobrazbe.
Pomemben dejavnik, tesno povezan z odzivom uporabnikov na nekatere mestne prostore, je tudi urbano vzdušje. Fenomenološki pristop $\mathrm{v}$ arhitekturi zagovarja prostorske koncepte, ki presegajo vidno zaznavanje, pri čemer vzdušje arhitekturnih objektov in mestnih javnih prostorov aktivira celotno zaznavo, vključno s tipom, vohom in sluhom (o tem so razpravljali Gaston Bachelard, Martin Heidegger, Christian Norberg-Schulz, Juhani Pallasmaa, Peter Zumthor in drugi). Raziskava urbanega vzdušja na javnih prostorih v Sarajevu (Zagora in Šamić, 2021) je pokazala, da je to, ali bodo javni prostori ustvarili multisenzorično izkušnjo, močno odvisno od njihove velikosti in stopnje odprtosti, pri čemer jih lahko razdelimo na ekstrovertirane javne prostore, za katere sta značilna formalno vzdušje in urbanost, ter introvertirane javne prostore, za katere sta značilna intimno vzdušje in občutek notranjosti. Družbeni vidik javnih prostorov lahko razumemo kot programsko opremo, fizični prostor pa kot strojno opremo. Razlaga in analiza kvantitativnih in kvalitativnih podatkov o aktivnostih in vzdušju na mestnih prostorih $\mathrm{v}$ realnem času v interaktivni geoprostorski podatkovni zbirki javnih prostorov lahko omogočita nov vpogled $\mathrm{v}$ razumevanje in morebitno preobrazbo izbranih območij in njihove širše okolice.

\section{Sklep}

Ena izmed posledic dolgotrajne tranzicije v Bosni in Hercegovini ter njene povojne, postsocialistične in postmoderne družbe je kriza javnih prostorov v Sarajevu, razvidna iz propadajočih, zanemarjenih in disfunkcionalnih skupnih mestnih prostorov ter težav, povezanih z njihovo dostopnostjo, lastništvom ter odtujenostjo od okolice in skupnosti. V navedenih okoliščinah so osnovne pravice ljudi do oblikovanja, uporabe, vzdrževanja ter ponovne uporabe in aktivacije skupnih prostorov v mestu težko uresničljive. Najpogostejše težave, $s$ katerimi se mesto spopada, so propadanje in izguba javnih prostorov ter nezakonito ali dvomljivo prilaščanje javnih zemljišč. Prostorske posledice zadnjih političnih in družbenoekonomskih sprememb spremlja tudi odpor ljudi do socialističnih vrednot, pri čemer je celo njihov odnos do koncepta skupnega prostora pogosto nejasen.

Težave v urbanem okolju današnjega Sarajeva so povezane s pomanjkanjem sodelovanja med strokovnjaki, javnim in zasebnim sektorjem ter lokalno skupnostjo, nezadostnimi javno dostopnimi podatki in redkimi razpravami, ki bi se osredotočale na javne prostore. Avtorici sta v raziskavi predpostavljali, da je razpoložljivost informacij eden ključnih temeljnih pogojev za razvoj učinkovitih javnih prostorov. Večina urbanističnih težav, ugotovljenih v Sarajevu, je posredna ali neposredna posledica razpršenosti informacij in ustreznih podatkov o zgodovini, lastništvu, dostopnosti, funkciji, upravljanju, stanju in 
okolici javnih prostorov. Avtorici zato predlagata metodologijo oblikovanja digitalne geoprostorske podatkovne zbirke javnih prostorov v Sarajevu. Kot kažejo primeri drugih uspešnih projektov, ki so vključevali digitalna orodja in proaktivno upravljanje javnih prostorov, bi morala predlagana podatkovna zbirka delovati kot obsežna, prosto dostopna interaktivna platforma. Namen rednega zbiranja in objavljanja vseh pomembnih in ažurnih podatkov o javnih prostorih $\mathrm{v}$ mestu bi morala biti transparentna in demokratična porazdelitev koristi, dolžnosti in pravic med lokalne oblasti, strokovnjake, zasebni sektor in lokalno skupnost. Kot je nakazano že v naslovu članka, je bil cilj raziskave nadomestiti dvoumni koncept nikogaršnjih prostorov oziroma prostorov, ki pripadajo komur koli ali neko$\mathrm{mu}, \mathrm{z}$ demokratično in izvirno oznako: prostori, ki pripadajo vsem. Eden izmed načinov doseganja navedenega je uporaba metodologije kartiranja: sistematičnega zbiranja in geolociranja različnih plasti podatkov o javnih prostorih. Kartiranje temelji na skupinah ključnih podatkov, povezanih $s$ funkcijo in dostopnostjo, urbano morfologijo in družbenim vidikom javnih prostorov, tem pa se lahko dodajo še druge kategorije in plasti. Pomembna funkcija, ki jo platforma omogoča, zajema tudi prekrivanje in združevanje raznovrstnih podatkov o javnih prostorih, kar zagotavlja nove multidisciplinarne poglede na to, kako se lahko izboljšajo, spremenijo, znova aktivirajo in nenazadnje vrnejo ljudem.

\section{Dina Šamić-Musemić \\ Opčina Sarajevo Centar, Sarajevo, Bosna in Hercegovina \\ E-naslov: dina.samic@centar.ba}

\section{Nermina Zagora}

Univerza v Sarajevu, Fakulteta za arhitekturo, Oddelek za arhitekturno oblikovanje, Sarajevo, Bosna in Hercegovina

E-naslov:nerminaz@af.unsa.ba

\section{Viri in literatura}

Carmona, M. (2010): Contemporary public space, part two: Classification. Journal of Urban Design, 15(2), str. 157-173. DOI: 10.1080/13574801003638111

Carr, S., Francis, M., Rivlin, L., in Stone, A. (1992): Public space. Cambridge, Cambridge University Press.

Centre for the Future of Places (2020): The public space database project. Dostopno na: https://www.kth.se/futureofplaces/research/current-research-pro/the-public-space-database-project-1.888450 (sneto 20. 6. 2020).

de Solà Morales, M. (1992): Public and collective space: The urbanisation of the private domain as a new challenge. La Vanguardia 12. 5. 1992, str. 33.

de Solà Morales, I. (2003): Territorios. Barcelona, Editorial Gustavo Gili.

Gehl, J. (2011): Life between buildings: Using public space. Washington, Island Press.

Gehl Architects (2020): Public life data protocol. Dostopno na: https:// gehlpeople.com/tools/public-life-data-protocol-beta/ (sneto 2. 5. 2020).
Gehl Institute (2017): Gehl institute. Dostopno na: https://gehlinstitute. org (sneto 26. 2. 2019).

Harrington, S., Dimitrijević, B., in Salama, A. (2017): Modernist architecture, conflict, heritage and resilience: The case of the historical museum of Bosnia and Herzegovina. Archnet-IJAR: International Journal of Architectural Research, 11(3), str. 178-192. DOI: $10.26687 /$ archnet-ijar.v11i3.1330

Husukić, E., in Zejnilović, E. (2017): Okoljska estetika Sarajeva: mesto, ki ga oblikujejo spomini. Urbani izziv, 28(1), str. 17-27. DOI: 10.5379/urbani-izziv-2017-28-01-002

Ibelings, H. (2010): Restart 1995-2010: Architecture in Bosnia and Herzegovina. Sarajevo, AABH Asocijacija arhitektata Bosne i Hercegovine.

Internet 1: http://www.popis2013.ba (sneto 29. 4. 2021).

Internet 2: http://www.visitsarajevo.ba (sneto 2. 5. 2020).

Internet 3: http://www.skenderija.ba (sneto 2. 5. 2020).

Internet 4: http://www.centar.ba (sneto 1. 5. 2020).

Internet 5: http://www.starigrad.ba (sneto 1. 5. 2020).

Internet 6: https://aabh.ba/12044-2/ (sneto 29. 4. 2021).

Internet 7: https://radiosarajevo.ba/metromahala/teme/dobre-kote-umjetnoscu-ozivljavaju-devastirane-javne-prostore-u-sarajevu/269919 (sneto 29. 4. 2021).

Karan, I., Stijak, M., in Kuvač, I. (2017): The small-scale approach as a generator for urbanity increase of Banja Luka city. V: Bijedić, D, Krstić Furundžić, A., in Zečević, M (ur.): Keeping up with technologies in the context of urban and rural synergy, str. 123-134. Sarajevo, Univerzitet u Sarajevu, Arhitektonski fakultet.

Klix (2021): Klix https://www.klix.ba/ (sneto 2. 5. 2021).

Kohn, M. (2004): Brave new neighborhoods. New York, Routledge. DOI: 10.4324/9780203495117

Koolhaas, R. (1997): The generic city. V: Koolhaas, R., Werlemann, H., in Mau B. (ur.): S M L XL, str. 1248-1264. New York, Monacelli Press.

Lefebvre, H. (1968): Le droit a la ville. Pariz, Anthropos.

LIFT (2015): Lift spatial initiative. Dostopno na: http://www.l-i-f-t.org/ (sneto 26. 2. 2019).

Loukaitou-Sideris, A., in Banerjee, T. (1998): Urban design downtown: Poetics and politics of form. Los Angeles, University of California Press.

Lynch, K. (1971): Site planning. Cambridge, MIT Press.

Općina Centar Sarajevo (2021): http://www.centar.ba/ (sneto 2. 5. 2021).

Općina Stari Grad Sarajevo (2021): http://starigrad.ba/v2/ (sneto 2. 5. 2021).

Oldenburg, R. (1997): The great good place: Cafes, coffee shops, bookstores, bars, hair salons, and other hangouts at the heart of a community. Cambridge, Da Capo Press.

Putnam, R. (2001): Bowling alone: The collapse and revival of American community. New York, Simon \& Schuster.

DOI: 10.1145/358916.361990

Seferagić, D. (2007): Akteri društvenih promjena u urbanom prostoru Hrvatske. Sociologija i prostor: časopis za istraživanje prostornoga i sociokulturnog razvoja, 45(3/4), str. 177-178.

Sennett, R. (2002): The fall of public man. London, Penguin Books.

Sorkin, M. (1992): Variations on a theme park: The new American city and the end of public space. New York, Hill \& Wang. 
UN-Habitat (2018): SDG Indicator 11.7.1 Training module: Public space. Nairobi, United Nations Human Settlement Programme. Dostopno na: https://unhabitat.org/sites/default/files/2020/07/indicator_11.7.1_training_module_public_space.pdf (sneto 19. 2. 2020).

United Nations Statistics Division (2020) Sustainable development goals. SDG Indicators. Dostopno na: https://unstats.un.org/sdgs/metadata/ (sneto 19. 2. 2020).

Varna, G., in Tiesdell, S. (2010): Assessing the publicness of public space: The star model of publicness. Journal of Urban Design, 15(4), str. 575-598. DOI: 10.1080/13574809.2010.502350

Zagora, N., in Šamić, D. (2014): Sarajevo lost in transition? Ideologies and their representational spaces. ArchNet International Journal of Architectural Research, 8(1), str. 159-170. DOI:10.26687/archnet-ijar.v8i1.313

Zagora, N., in Šamić, D. (2021): Urban rooms of Sarajevo: Transforming urban public spaces using interior design tools. Sarajevo, Univerzitet u Sarajevu, Arhitektonski fakultet Sarajevo.

Zlatar Gamberožić, J. (2019): Revitalization paths of urban centers: Tentative observational comparison of two cities - Ljubljana and Zagreb. Družboslovne razprave, 90 , str. 83-106.

Zukin, S. (1995): The cultures of cities. Oxford, Basil Blackwell. 